Universal Decimal Classification (UDC) 616.12-06: 616-018.74-031: 611.1]-057: 625.282

\title{
INTERACTION BETWEEN RISK FACTORS OF PREMORBID PATHOLOGIES AND DYSFUNCTION PREDICTORS OF ENDOTHELIAL OF A LOCOMOTIVE DEPOT'S GROUP OF WORKERS
}

\section{N.N. Malyutina, L.A. Taranenko, A.S. Tolkach, M.S. Nevzorova}

SBEI HPE "Perm State Medical University named after E.A.Wagner" of Ministry of Health of Russian Federation, 26 Petropavlovskaya St., Perm, Russian Federation, 614990

The article proved a stable connection between an essential hypertension (EH) development, life-threatening arrhythmias and conduction under the impact of a complex of occupational factors, first of all psycho-emotional stress, noise and electromagnetic radiation. We analyzed the initial manifestations of endothelial dysfunction of the locomotive engine drivers. We found an increase of the performance of endothelin-1 (1.59 $\pm 0.29 \mathrm{p} / \mathrm{mole} / \mathrm{ml}), \mathrm{MCP}-1(268.83 \pm 23.29 \mathrm{pg} / \mathrm{ml})$. Revealed changes are proposed as laboratory predictors and forecast criteria of initial lesion of the vascular bed.

Key words: illness, work-related, endothelial dysfunction, hypertension, arrhythmias and conductibility.

Background. Cardiovascular diseases are the leading causes of disability and death among elderly and working-age patients. About 17 million people die of cardiovascular diseases annually [2]. In 2014, mortality from cardiovascular diseases in Russia totaled 650 deaths per 100 thousand inhabitants. More than $30 \%$ of cases of death take place among the working-age population.

Train driving is a popular career in Russia. Engine crew members, drivers in particular, face a high level of job-related stress and the risk of accidents [4]. The risks of arterial hypertension $(\mathrm{AH})$ and coronary artery disease (CAD) are 3 and 2-3 times higher respectively in those exposed to continuous psycho-emotional and physical stress [11]. The specificity of the profession requires train drivers to have a healthy central nervous system (CNS) since the labor conditions (including management of a fast-moving object in a monotonous environment, alertness, and a high level of responsibility for passengers' lives) create report that $94.4 \%$ of sudden deaths among train drivers and their assistants are caused by cardiovascular catastrophes [1]. Recent research studies indicate that sudden cardiac death (SCD) can be caused by $\mathrm{AH}$ or asymptomatic CAD. Today Russian Railroads implements an employee-oriented Task Program aimed at decreasing professional morbidity and preventing deaths from circulatory diseases [4].

The analysis of the markers that describe the functional condition of the endothelial lining of the vascular bed as cardiovascular risk factors is the most accurate component in early detection of SCD [5].

Purpose of the research is to study the impact of the labor conditions including job-related risks on the development of hypertensive disease and lifethreatening arrhythmia, determine the clinical informative value of the indicators of endothelium dysfunction as a predictor of the development of a cardiovascular pathology among the engine crew

(C) Malyutina N.N., Taranenko L.A., Tolkach A.S., Nevzorova M.S., 2015

Malyutina Natalia Nikolaevna - MD, head of the department of faculty therapy and occupational diseases № 2 with a course of occupational diseases Department of Additional Professional Education (e-mail: dr-malyutina@yandex.ru; tel.: +7 9638801708).

Taranenko Lyudmila Andreevna - MD, associate professor of faculty therapy № 2 and occupational diseases, with a course of occupational diseases Department of Additional Professional Education (e-mail: taranenko-la@yandex.ru; tel.: +7 9194550417).

Tolkach Anna Sergeevna - graduate student of the 3rd year of the faculty therapy № 2 and occupational diseases, with a course of occupational diseases Department of Additional Professional Education (e-mail: tolkach.anya@yandex.ru; tel.: +7 9124877684).

Nevzorova Marina Sergeevna - PhD, assistant of the department of biochemistry (e-mail: nevzorova.ms@mail.ru; tel.: +7 9504578348)

a permanent stressful environment thus increasing members.

the risk of somatic diseases $[9,11]$. Many sources 
Materials and methods. The study was carried out at the non-government healthcare institution OKB at Perm 2 under Russian Railroads. The study included 105 employees: the first group was composed of 45 train operators and operator assistants with confirmed essential hypertension $(\mathrm{EH})$; the second group included 30 healthy train operators and their assistants. The comparison group included 30 men who did not face any harmful or hazardous job-related factors. The average age of the respondents in the first group totaled: $44,2 \pm$ 8,85 years old, and the second group: $36,3 \pm 8,86$ years old, and the comparison group: $42,5 \pm 8,31$ years old. The groups were compared in terms of length of employment, gender, and age.

The study included laboratory tests to determine the level of endothelin-1 with enzymelinked immunosorbent assay (ELISA) by using the assay kits by Biosourse, EuropeS.A, and enzyme immunoassay analyzer Stat-Fax-2100. The level of cytokine MCP-1 in blood serum was determined with the help of ELISA by using the test systems by Vektor Best, Novosibirsk, and enzyme immunoassay analyzer Stat-Fax-2100.

Data Processing. Data processing was performed by using Statistica 6.0 and StatPlus 2009 Professional 5.8.4. The significance of differences was assessed with the help of Student's t-test. The null hypothesis was rejected, and differences between the samples were considered statistically significant at alpha-error less than $0,05[3,7]$. When analyzing the data, the odds ratio (OR), confidence interval $(95 \% \mathrm{CI})$, relative risk (RR), and etiological fraction $(\mathrm{EF}, \%)$ were calculated. The relationship between the state of health and labor conditions was assessed by using Denisov scale, 2003 and the Professional Risk interactive reference guide. The reference (threshold) risk was calculated which indicates a statistical lower confidence contour of exposure that leads to negative effects. At this exposure level, a $10 \%$ excess risk among the individuals below the second and above the $98^{\text {th }}$ percentile in the event of normal response distribution in terms of health.

Results. A sanitary and hygienic analysis of the labor conditions showed that locomotive drivers work in four shifts, alternating day and night shifts, 12 hours per shift. The workplace air contained exhaust diesel engine gases including carbon monoxide - 11,5 $\pm 3,6 \mathrm{mg} / \mathrm{m}^{3}$ (MAL $20 \mathrm{mg} / \mathrm{m}^{3}$ ), nitrogen oxides $-1,9 \pm 0,7 \mathrm{mg} / \mathrm{m}^{3}$ (MAL $5 \mathrm{mg} / \mathrm{m}^{3}$ ), acrolein - 0,1 $\pm 0,02 \mathrm{mg} / \mathrm{m}^{3}$ (MAL $0,2 \mathrm{mg} / \mathrm{m}^{3}$ ), saturated aliphatic carbons C1-C10 - 150 $\pm 14,5$ $\mathrm{mg} / \mathrm{m}^{3}$ (MAL $900 \mathrm{mg} / \mathrm{m}^{3}$ ); the duration of exposure to the chemical factor totals $90 \%$ of a work shift which corresponds to the second "permissible" class. The noise from power and auxiliary units, wheel-rail interaction, and a walky-talky that works during the entire route take up to $80 \%$ of the shift. The equivalent noise level totaled $82,5 \pm 1,52 \mathrm{dBA}$ while $\mathrm{MAL}=80 \mathrm{dBA}$. The labor conditions class equals 3.1 which means "hazardous". The general vibration transmitted thought the floor and seats is at the permissible level 113,3 $\pm 1,52 \mathrm{dBA}$. Exposure to vibration takes up to $80 \%$ of a work shift which corresponds to class 2 which means "permissible". Electromagnetic ionizing and non-ionizing radiation sources correspond to class 3.1 which means "hazardous". In terms of workplace illumination, the labor conditions correspond to class 2 which means "permissible". Train operators follow a number of instructions, work under time pressure, and are expected to show a high level of responsibility. Any mistake can result in damaged equipment, stopping of a technological process, creation of a situation that can be dangerous to own life or the lives of others. The job of a locomotive driver is of average intensity which falls under class 3.1 which means "hazardous". According to the rules of integral assessment of labor conditions, if a job is described by 3 or more factors under class 3.1, then the labor conditions are considered "hazardous", and assigned the degree 3.2. The labor conditions of train operators of Perm office of Sverdlovsk Railroad are considered "hazardous", and assigned the degree 3.2.

In the first group, the following risk factors leading to cardiovascular diseases prevail among the train operators: smoking - 32\%, obesity $-30 \%$, and family history $-28 \%$. It was found that in the group of locomotive drivers, HD is diagnosed at an earlier age of $38,7 \pm 6,14$ years old as compared to $43,2 \pm 5,2$ years old in the comparison group. The length of employment at the time of HD diagnostics is also significantly shorter in the group of operators $(16,1 \pm 6,4$ years old as compared to the group of respondents who are not employed in the railroad industry $(22,01 \pm 8,1$ years old). The average length of employment is 6 years $(\mathrm{p}=0,0001)$. The risk of $\mathrm{HD}$ onset among the operators employed for less than 15 years is as follows: OR $=2,84(95 \% \mathrm{CI} 1,23$ $-6,56) ; \mathrm{RR}=2,4(95 \% \mathrm{CI} 1,19-4,83)$, calculated value $\chi^{2}=5,98$ (table 3,8$), \mathrm{EF}=58 \%$. [8]. Probability assessment of the nature of a health disorder indicates that the disorder is job-related.

When analyzing the structure of HD, it was revealed that the first and second degrees of arterial hypertension are diagnosed more frequently than in 
the comparison group $(\mathrm{p}<0,05)$, and the third degree is diagnosed significantly less frequently $(p<0,05)$ due to counterindications and suspension from work.

The analysis of complaints and medical background, cardiovascular history in particular, of operators diagnosed with HD shows a very low activity in sharing complaints (43\%) as compared to the comparison group $(86 \%), p<0,05$. The number of complaints expectedly grows with longer employment; the same trend pertains in the comparison group. However the operators have a negative correlation which indicates "a healthy employee syndrome" since development of HD among transport operators is a big indicator of professional aptitude.

Rhythm disturbance and impaired conductivity are more frequent among operators, according to the analysis. The breakdown of these disorders is as follows: auricular extrasystole - 66\% (against 46\% in the comparison group), ventricular premature beats - 54\% (against 29\% in the comparison group), tachyrhythmia - 6\% (against $1 \%$ in the comparison group), second degree atrio-ventricular (AV) blocks - $6 \%$ (against $0 \%$ in the comparison group), sinoatrial nodal blocks - 9\% (against $0 \%$ in the comparison group) of cases. Almost $90 \%$ of the operators in training were diagnosed with rhythm disturbance and impaired conductivity, and about half were diagnosed with both. Calculation of the odds and risks of rhythm disturbance and impaired conductivity gave the following results: $\mathrm{OR}=4.14$ $(95 \% \mathrm{CI} 2.25-7.59) ; \mathrm{RR}=1.78(95 \% \mathrm{CI} 1.39-$ 2.28 ), calculated value $\chi 2=21.08$ (table 3.8 ), $\mathrm{EF}=$ $44 \%$. Probability assessment of the nature of a health disorder indicates that the disorder is jobrelated.

High incidence of rhythm disturbance and impaired conductivity is likely associated with the neurogenic impact by stimulation of the sympathic innervation of the cardiac conducting system. Electromagnetic irradiation has a depressing effect on the parasympathetic regulation of the heart rate and on the pulse generation, which leads to rhythm disturbances and impaired conductivity. These disorders coupled with increased arterial pressure are undoubtedly dangerous because they because they can result in arrhythmias and paroxysmal syncope as a predictor of urgent situations

Analysis of the functional state of endothelium revealed significant changes in the group of employees in training diagnosed with HD. The studies showed that endothelium dysfunction in the operators in training (diagnosed with increased arterial pressure) is more expressed that in other analyzed groups (Table

1).

Table 1

Endothelium dysfunction among the engine crew members

\begin{tabular}{|c|c|c|c|c|}
\hline \multirow{2}{*}{ Indicator } & $\begin{array}{c}\text { Operators with } \\
\text { HD }\end{array}$ & $\begin{array}{c}\text { Operators without } \\
\text { HD }\end{array}$ & Comparison group & \multirow{2}{*}{$\begin{array}{c}\text { Significant differences } \\
\text { between the groups }\end{array}$} \\
\cline { 2 - 4 } & 1 & 2 & 3 & $\begin{array}{c}p_{1 / 2}=0,048 \\
p_{1 / 3}=0,001\end{array}$ \\
\hline Endothelin-1 & $1,59 \pm 0,29$ & $0,86 \pm 0,08$ & $0,23 \pm 0,02$ & $\begin{array}{c}p_{1 / 2}=0,001 \\
p_{1 / 3}=0,00001\end{array}$ \\
\hline MCP-1 & $268,83 \pm 23,29$ & $146,78 \pm 9,22$ & $22,34 \pm 3,11$ & \\
\hline
\end{tabular}

Endothelin-1 is an expressed vasoconstrictor which increases with affected endothelium. It does not accumulate in endothelial cells, but forms quickly under the impact of many factors including epinephrine, angiotensin-II, vasopressin, thrombin, cytokines, and mechanical influences. This is why its indicators are higher in the group of operators without HD. At the same time, the indicators in the comparison group are significantly different.

The level of MCP-1 in blood serum was reported significantly higher as compared to other analyzed groups. Given the basic properties of this cytokine including participation in the stimulation of pathological angiogenesis of cancer, autoimmune and vascular diseases, it is considered a bad prognostic sign which indicates a high risk of aforementioned diseases [6].

Consequently, despite the absence of complaints, ambiguity of the clinical findings, satisfactory general clinical and biochemical blood tests, it is suggested early signs of endothelial dysfunction, including their predictive criteria, be detected at the preclinical stage of the diagnosis of the cardiovascular disease among enginge crews members.

\section{Conclusion:}

1. The labor conditions of locomotive drivers are considered "hazardous", hazard level 3.2 is determined by a high level of production noise, intense labor process, and high electromagnetic indicators. 
2. Hypertensive disease was proved to be jobrelated. An early onset of HD was registered in the operators with less than 15 years of employment as well as increased arterial pressure (first and second degree). A negative correlation was revealed between the complaints and the length of employment of operators which indicates concealment caused by the direct connection between HD and professional aptitude of operators.

3. A high incidence of rhythm disturbance and impaired conductivity was found in the operators with HD which indicates a negative impact of the workplace factors, primarily electromagnetic interference, noise, vibration, and psycho-emotional stress.

4. Initial presentation of endothelial dysfunction was diagnosed associated with the discharge of endothelin-1, MCP-1 into the blood stream. These indicators are viewed as laboratory predictors and prediction criteria of the early stages of the blood stream disease.

\section{References}

1. Vil'k M.F. Departament zdravoohranenija MPS. Organizacionnye aspekty snizhenija riska vnezapnoj smerti u mashinistov lokomotivov [Department of Health of the Ministry of Railways. Organizational aspects of reducing the risk of sudden death of locomotive drivers]. Zheleznodorozhnaja medicina, 2001, no. 2, pp. 11-16. (in Russian).

2. Goluhova E.Z. Zabolevanija serdechno-sosudistoj sistemy - pandemija sovremennoj jepohi. Social'noe znachenie i posledstvija [Cardiovascular system diseases - a pandemic of the modern era. Social significance and consequences]. Associacija serdechno-sosudistyh hirurgov Rossii. Sekcija "Kardiologija i vizualizacija v kardiohirurgii", 2006, Available at: http: //heart-master.com/clinic/cardiovascular_disease (28.10.2015). (in Russian).

3. Glanc S. Mediko-biologicheskaja statistika (per. s angl.) [Biomedical Statistics (translated from English)]. Moscow: Praktika, 1998, 459 p. (in Russian).

4. Plohov V.N., Lazarev V.N., Bystrov V.V., Martynova G.G., At'kov O.Ju. Kompleksnyj podhod k ohrane zdorov'ja rabotnikov OAO «RZhD» [Complex approach to health care of workers of JSC "Russian Railways"]. Medecina truda i promyshlennaja jekologija, 2015, no. 9, pp. 115-116. (in Russian).

5. Nikitina V.V., Zaharova N.B. Znachenie MSR-1 kakprediktorasosudistyh narushenij [MCP-1 value as a predictor of vascular disorders]. Saratovskij nauchno-medicinskijzhurnal, 2010, vol. 6, no. 4, pp. 786-790. (in Russian).

6. Petri A., Sjebin, K. Nagljadnaja medicinskaja statistika [Visual medical statistics]. Moscow: Gjeotar Media, 2009,168 p. (in Russian).

7. Izmerova N.F., Denisova Je.I. Professional'nyj risk dlja zdorov'ja rabotnikov: Rukovodstvo [Occupational health risks for workers: Guide]. Moscow: Trovant, 2003, 448 p.

8. Malyutina N.N., Nevzorova M.S., Taranenko L.A., Tolkach A.S. Pat. 2512704 Rossijskaja Federacija. Sposob diagnostiki narushenij mikrocirkuljacii pri osteoartroze u zhenshhin, rabotajushhih v uslovijah fizicheskogo perenaprjazhenija. Zajavitel' i patentoobladatel' Gosudarstvennoe bjudzhetnoe obrazovatel'noe uchrezhdenie vysshego professional'nogo obrazovanija "Permskaja gosudarstvennaja medicinskaja akademija imeni akademika E.A. Vagnera" Ministerstva zdravoohranenija i social'nogo razvitija Rossijskoj Federacii (RU). - 2012148076/15; zajavl. 12.11.2012; opubl. 10.04.2014, Bjul. № 10. [Pat. 2512704 Russian Federation. A method for diagnosing disorders of the microcirculation in osteoarthritis in women working in conditions of physical stress. The applicant and patentee state budgetary is educational institution of higher education "Perm State Medical Academy named after Academician E.A. Wagner" of the Ministry of Health and Social Development of the Russian Federation (RU). - 2012148076/15; appl. 12.11.2012; publ. 04.10.2014, Bull. № 10]. (in Russian).

9. Turashvili G.A. Jekspertnaja ocenka vlijanija nekotoryh faktorov na vozniknovenie i razvitie gipertonicheskoj bolezni [Expert evaluation of the impact of certain factors on the occurrence and development of essential hypertension]. Sovremennaja medicina, 1978, no. 1, pp. 149-150. (in Russian).

10. Folkov B. Jemocional'nyj stress i ego znachenie dlja razvitija serdechno-sosudistyh zabolevanij [Emotional stress and its importance for the development of cardiovascular diseases]. Kardiologija, 2007, no. 10, pp. 4-11. (in Russian).

11. Cfasman A.Z. Vnezapnaja serdechnaja smert' (i ee professional'nye aspekty) [Sudden cardiac death (and its professional aspects)]. Moscow: MCNMO, 2003, 302 s. (in Russian). 